\title{
Circulating immune complexes and monocyte Fc function in autoimmune diseases
}

\author{
MÁRIA KÁVAI, KATALIN LUKÁCS, ILDIKÓ SONKOLY, \\ KATALIN PÁLÓCZI, AND GY. SZEGEDI
}

From the Department of Pulmonary Diseases, Division of Medicine, University Medical School of Debrecen, Hungary

SUMmARY The phagocytosis of separated and adherent monocytes of patients with systemic lupus erythematosus is subnormal as compared to controls on the basis of latex and yeast uptake. The monocytes from the same patients react with antibody-coated sheep red blood cells in a significantly higher degree than normal monocytes. There is a correlation between the percentage of reactive monocytes and the serum immune complex content. After brief treatment of patients with levamisole the phagocytic function of monocytes is restored and at the same time the circulating immune complex content is decreased.

Patients with autoimmune connective tissue disorders display immunological hyperreactivity characterised by the formation of numerous autoantibodies and immune complexes (Johnson et al., 1975; Mulli and Cruchaud, 1977; Winfield et al., 1977). In addition to the alteration of humoral immunity there is an impairment of cell mediated immunity (CMI) (Utsinger, 1976). Recently Landry (1977) has shown that the impaired function of phagocytes rather than of lymphocytes may be responsible for alteration of CMI in systemic lupus erythematosus (SLE).

In this study we report impaired function of blood monocytes and the presence of circulating immune complexes (CIC) in the same patients with SLE. Alteration of monocyte function may be directly related to serum immune complexes (Rabinovitch et al., 1975).

\section{Patients and methods}

\section{PATIENTS}

Twenty-nine patients with SLE were selected, 2 men and 27 women. Twenty of the patients were not receiving treatment at the time of the test. The patients fulfilled the preliminary ARA criteria for SLE (Cohen et al., 1971). Nine patients had received levamisole $150 \mathrm{mg}$ daily, every other day for a week. Sixteen controls were selected from among volunteers.

Accepted for publication 15 March 1978.

Correspondence to Dr Maria Kavai, Department of Pulmonary Diseases, University Medical School, 4004 Debrecen 4 , Hungary.
CIRCULATING IMMUNE COMPLEXES

Immune complex assays were performed by a modification of the Onyewotu et al. (1974) technique. The ingestion of labelled aggregated IgG by guineapig peritoneal macrophages was inhibited in the presence of serum containing IC. $10^{6}$ macrophages in $0.5 \mathrm{ml}$ medium 199 (Flow) modified with Hanks's salts and HEPES buffer were incubated for $75 \mathrm{~min}$ at $37^{\circ} \mathrm{C}$ with $4 \mu \mathrm{g}{ }^{125} \mathrm{I}$-aggregated human IgG and with $10 \mu \mathrm{l}$ of a 1:5 dilution of SLE or control serum (Kávai et al., 1977). All tests were performed in triplicate in siliconised glass tubes. After incubation the cells were washed 3 times, and the radioactivity of pellets was counted in a Packard automatic counter. The IC content of the sera was expressed in inhibition $\%$.

\section{SEPARATION OF MONOCYTES}

Human monocytes were obtained by the method of Weston et al. (1975). $15 \mathrm{ml}$ of heparinised venous blood from patients and controls was sedimented in Ficoll-Uromiro gradients. After washing, the cells were suspended in $1 \mathrm{ml}$ of medium 199 and counted with a stardard haemocytometer. Trypan blue viability and neutral red phagocytosis were performed on the cells to determine the percentage of phagocytic cells and their viability.

\section{MONOCYTE PHAGOCYTOSIS}

A monolayer technique was used with the cells adherent to a glass slide in Boyden chamber. After washing, the monocytes $\left(0.5-1.0 \times 10^{5}\right.$ cells) were incubated with $25 \mu \mathrm{l}$ of a $0 \cdot 2 \%$ suspension of latex 
particles (Dow, $0.481 \mu \phi$ ) or with $25 \mu$ l of a suspension of baker's yeast containing $5 \times 10^{6}$ particles, together with $0.5 \mathrm{ml}$ medium 199. Incubation was at $37^{\circ} \mathrm{C}$ for $60 \mathrm{~min}$ in $5 \% \mathrm{CO}_{2}$ and $100 \%$ humidity with constant rocking. After washing, the monolayers were stained with Türk's or Wright's stain, and cells containing ingested particles were counted. The percentage of cells ingesting latex particles, and of cells ingesting or attaching yeast, and also the number of yeast particles ingested per cell (phagocytic index) was determined.

\section{MONOCYTE OPSONISATION}

Monolayers of adherent monocytes were incubated as above at $37^{\circ} \mathrm{C}$ for $60 \mathrm{~min}$ with $25 \mu \mathrm{l}$ of $2 \times 10^{8}$ particles $/ \mathrm{ml}$ yeast which had been treated with $0 \cdot 1$ $\mathrm{ml}$ of $\mathrm{AB}$ human serum as opsonin and washed. After washing and staining, the percentage of cells ingesting or attaching yeast and the number of yeast particles ingested per cell was determined.

In a separate experiment the yeast particles were incubated with $\mathrm{AB}$ serum in the same ratio for 60 min at $37^{\circ} \mathrm{C}$. After washing, the opsonised yeast particles were incubated with fluorescein conjugated antihuman IgG, IgA, IgM, and complement C3 antisera (Hyland) and examined by fluorescent microscopy.

\section{MONOCYTE EA ROSETTE}

Monocyte Fc receptor activity was assayed by adherence of sheep red blood cells (SRBC) coated with a subagglutinating dilution $(1: 128)$ of an IgG fraction isolated on Sephadex G-200 from a rabbit anti-SRBC serum. The adherent monocytes were incubated with $0.2 \mathrm{ml}$ of $2 \%$ sensitised SRBC in $0.3 \mathrm{ml}$ medium 199 at $37^{\circ} \mathrm{C}$ for $30 \mathrm{~min}$. After washing, the percentage of cells attaching or ingesting 3 or more SRBC was determined.

\section{Results}

\section{CIRCULATING IMMUNE COMPLEXES}

The patients' sera inhibited the ingestion of labelled aggregated IgG by macrophages to a significantly greater extent $(48 \cdot 1 \pm 22 \cdot 8 \%$ inhibition) than normal sera $(7 \cdot 8 \pm 5 \cdot 9 \%$ inhibition). The individual results are shown in Fig. 3.

\section{PHAGOCYTOSIS OF MONOCYTES}

Separated mononuclear leucocyte suspensions derived from peripheral blood by Ficoll-Uromiro density gradient centrifugation contained 25-30\% monocytes. Monolayers of these mononuclear cells were prepared. The non-adherent cells were removed, then adherent cells, 85-99\% monocytes, were analysed. In Fig. 1 it is shown that the phagocytostiks of monocytes is subnormal in patients with SLE as compared with controls.

\section{REACTIVE MONOCYTES}

In this experiment the separated and adhereat. monocytes from the same patients and controls were incubated with sensitised SRBC or with opsonisefl, yeast. Monocytes from the patients reacted with antibody-coated SRBC to a significantly greater extent than normal monocytes (Fig. 2).

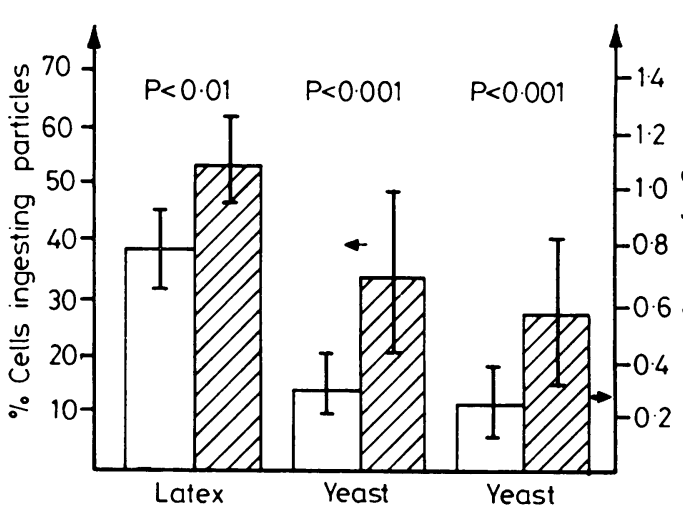

Fig. 1 In vitro phagocytic activity of monocytes from paticnts $\square$ and controls. $\square$

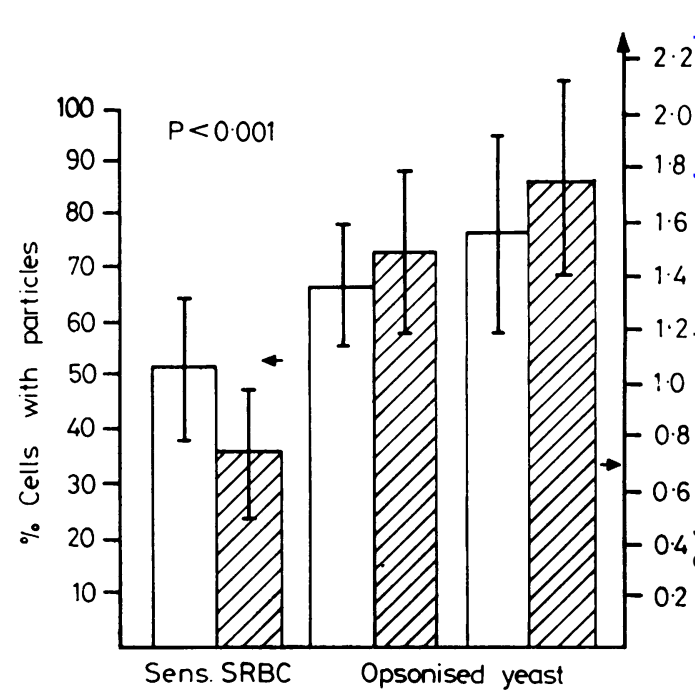

Fig. 2 Percentages of monocytes from patients and controls $Q Z 7$ reactive with sensitised $S R B C$ or opsonised yeast particles. 
No significant difference between the 2 groups was found in their ability to attach or phagocytose opsonised yeast. By immunofluorescence C3 could be demonstrated on the surface of each opsonised yeast particle but IgM only on $28 \%$ of the opsonised yeast particles.

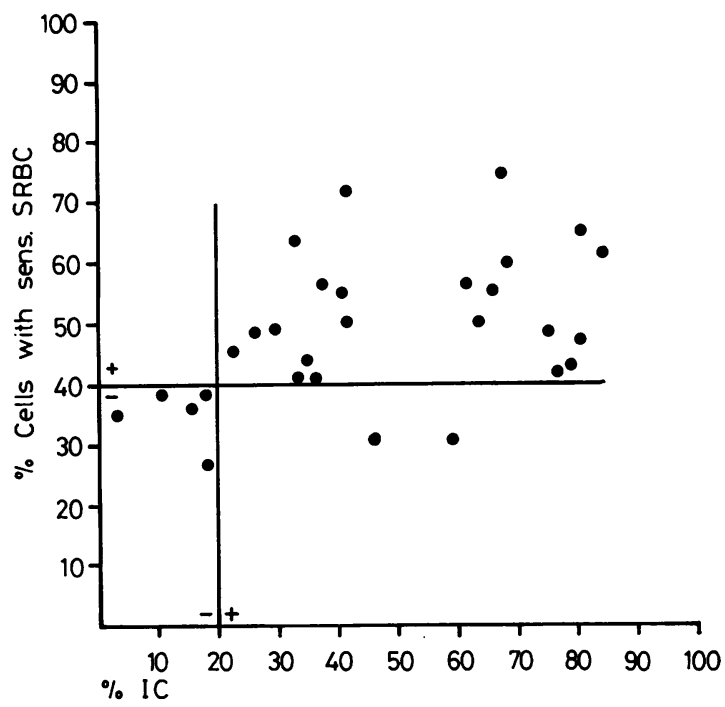

Fig. 3 Correlation between the percentage of monocytes attaching or ingesting sensitised SRBC and the serum IC content of the same patient.

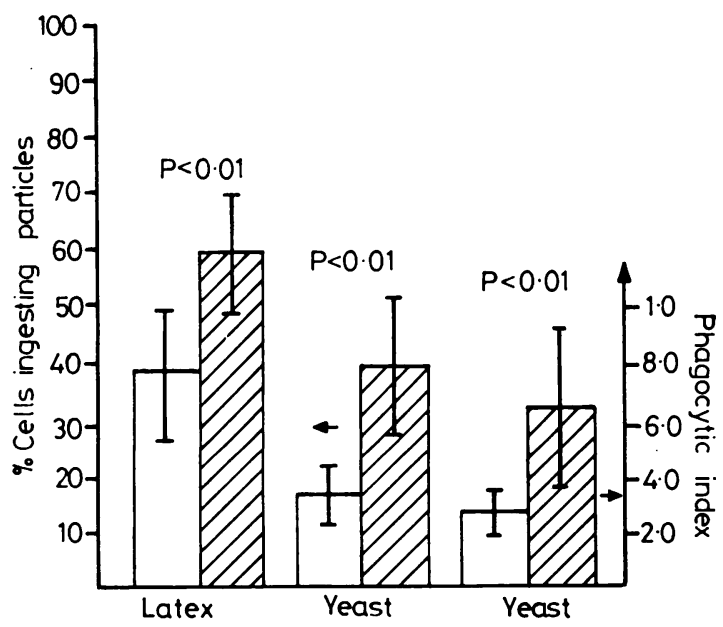

Fig. 4 Effects of levamisole on phagocytic activity for latex and yeast of monocytes from patients. $\square=$ before treatment. $Z Z=$ after treatment.

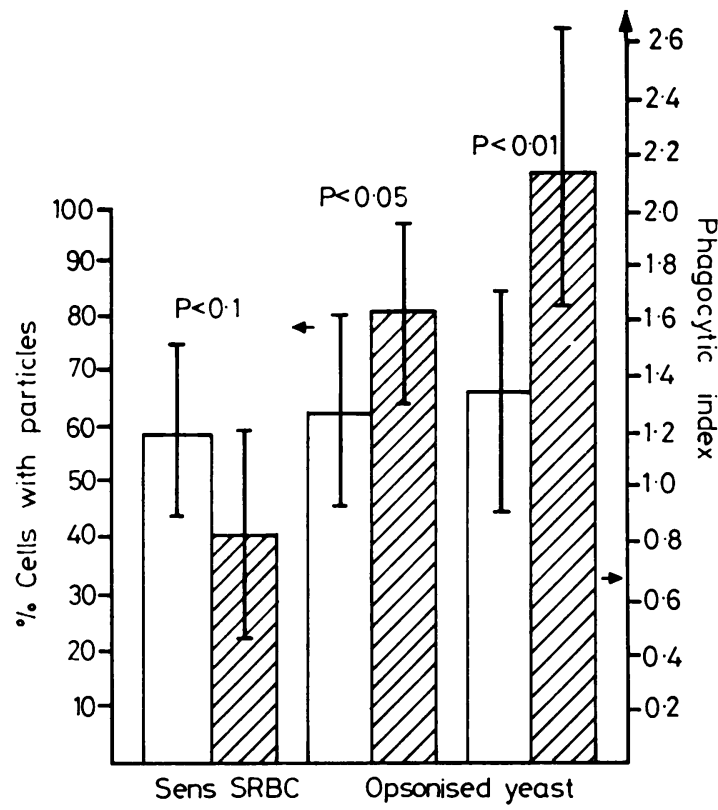

Fig. 5 Effects of levamisole on patients' monocyte uptake of sensitised SRBC and opsonised yeast particles, before treatment, $\mathrm{Z}$ after treatment.

Fig. 3 shows the correlation between the percentage of monocytes ingesting or attaching sensitised SRBC and the IC content of the same patients' sera. Patients having high circulating IC in most cases had monocytes with increased Fc activity.

\section{LEVAMISOLE TREATMENT OF PATIENTS}

Following levamisole treatment for 1 week phagocytosis of latex and yeast increased to normal levels (Fig. 4). The reactivity of patients' monocytes with opsonised yeast particles increased as well, but on the basis of reactivity with sensitised SRBC monocyte Fc activity was unchanged (Fig. 5).

In parallel with increased phagocytosis we observed decreased serum IC content except in 1 case (Table 1). The Table shows that the monocyte FC receptor activity was altered together with CIC of patients in 7 cases out of 9 after levamisole treatment.

\section{Discussion}

Adequate phagocytic capacity is essential for development of delayed hypersensitivity reactions. The reduced cutaneous response of patients with SLE may result from the reduced phagocytic ability of the 
Table 1 Effects of levamisole on monocyte IgG receptor activity and on circulating immune complexes

\begin{tabular}{|c|c|c|c|c|}
\hline \multirow[b]{2}{*}{ Patients } & \multicolumn{2}{|l|}{$M-E A \%$} & \multicolumn{2}{|l|}{ CIC \% } \\
\hline & $\begin{array}{l}\text { Before } \\
\text { treatment }\end{array}$ & $\begin{array}{l}\text { After } \\
\text { treatment }\end{array}$ & $\begin{array}{l}\text { Before } \\
\text { treatment }\end{array}$ & $\begin{array}{l}\text { After } \\
\text { treatment }\end{array}$ \\
\hline $\begin{array}{l}1 \\
2 \\
3 \\
4 \\
5 \\
6 \\
7 \\
8 \\
8 \\
9\end{array}$ & $\begin{array}{l}58 \cdot 9 \\
35 \cdot 2 \\
43 \cdot 3 \\
50 \cdot 6 \\
75 \cdot 0 \\
56 \cdot 3 \\
55 \cdot 9 \\
82 \cdot 5 \\
72 \cdot 3\end{array}$ & $\begin{array}{l}71 \cdot 0 \\
65 \cdot 2 \\
42 \cdot 0 \\
51 \cdot 0 \\
32 \cdot 3 \\
24 \cdot 1 \\
32 \cdot 7 \\
13 \cdot 4 \\
41 \cdot 3\end{array}$ & $\begin{array}{r}0 \\
0 \\
23 \\
63 \\
67 \\
65 \\
40 \\
33 \\
38\end{array}$ & $\begin{array}{r}0 \\
72 \\
16 \\
40 \\
22 \\
51 \\
25 \\
12 \\
24\end{array}$ \\
\hline
\end{tabular}

M-EA $\%=\%$ monocytes with erythrocyte-antibody. CIC $\%=$ circulating immune complex $\%$

polymorphonuclear leucocytes and monocytemacrophages. Impaired phagocytic ability of polymorphonuclear leucocytes in SLE has been reported (Besana et al., 1975; Zurier, 1976), and the phagocytic function of monocytes in SLE has also been questioned (Wenger and Bole, 1973; Landry, 1977). The present studies demonstrate impaired phagocytosis of latex particles and baker's yeast by monocytes in 29 patients with SLE. The CIC content of the same patients was significantly higher than that of controls. The data of Haakenstad and Mannik (1974) support our findings. In vivo administration of IC to the subject results in a subsequent decrease in the clearance rate of particulate matter from circulation.

We have also shown, however, that monocytes from patients with SLE react with antibody-coated SRBC to a significantly greater extent than normal monocytes, indicating increased monocyte IgG receptor activity. These data of normal monocytes are well supported by the same experiments of Reikvam (1977). The reason for this Fc receptor activation in SLE is unknown.

Increased activity of monocytes to bind antibodycoated SRBC was reported in patients with malignant lymphoma (LoBuglio, 1970; Saragome et al., 1977) and in sarcoidosis (Douglas and Daughaday, 1976).

As the Fc receptor has a specially important role in the ingestion of $\mathrm{IgG}$ antibody-antigen complexes (Mannik et al., 1974), the permanent presence of IC may elicit an increased net synthesis of membrane which contributes to activation of Fc receptor sites. This may account for differences in the immune and non-immune interaction of the monocyte-macrophage system with particles (Weiner and Bandieri, 1977; Walker, 1974).

In SLE Fc receptor activity towards opsonised yeast is not increased, as shown in Fig. 2. We could detect mainly $\mathrm{C} 3$ and IgM on the opsonised yeast

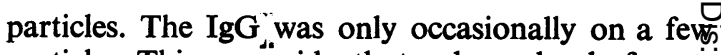
particles. This was evidently too low a level of coat ing to reveal the increased reactivity demonstrate with sensitised SRBC.

Schmidt and Douglas (1976) have reported tha的 levamisole increases in vitro phagocytosis of bacteri的 by mononuclear phagocytes. After brief treatmen $\$$ of the patients in the present study with levamisoles the phagocytic function of their monocytes was restored, as reported by Symoeus (1976), and in parallel the CIC content decreased. After levamisole treatment the increased reactivity of the monocytes? was demonstrable even with opsonised yeast particles $\frac{0}{2}$

The authors are grateful to Dr E. J. Holborow for his helpful discussion and kind revision of the manuscript.

\section{References}

Besana, C., Lazzarin, A., Capsoni, F., Caradda, F., an Maroni, M. (1975). Phagocyte function in systemic lupuș erythematosus. Lancet, 2, 918-918.

Douglas, S. D., and Daughaday, C. C. (1976). Kinetics of monocyte receptor activity for immunoproteins in patients with sarcoidosis. Annals of the New York Academy of Sciences, 278, 190-200.

Haakenstad, A. O., and Mannik, M. (1974). Saturation of the reticuloendothelial system with soluble immune complexes Journal of Immunology, 112, 1939-1948.

Huber, H., and Fudenberg, H. H. (1968). Receptor sites of human monocytes for IgG. International Archives of Allergy and Applied Immunology, 34, 18-31.

Cohen, A. S., Reynolds, W. E., Franklin, E. C., Kulka, J. P. $\overrightarrow{\bar{O}}$ Ropes, M. W., Shulman, L. E., and Wallace, S. L. (1971) 3 Preliminary criteria for the classification of systemic lupus erythematosus. Bulletin on Rheumatic Diseases, 21, 643648.

Johnson, P. M., Watkins, J., and Holborow, E. J. (1975) Antiglobulin production to altered IgG in rheumatoide arthritis. Lancet, 1, 611-614.

Kávai, M., Dankó, K., Kalmár, E., Francia, I., and Szegedi Gy. (1977). Radioassay of soluble immune complexes using their uptake by macrophage Fc receptors. Immuno--3 $\log y, 32,617-621$.

Landry, M. (1977). Phagocyte function and cell-mediated immunity in systemic lupus erythematosus. Archives of Dermatology, 113, 147-154.

LoBuglio, A. (1970). Effect of neoplasia on human macrophage membrane activity. Journal of Laboratory and Clini $N$ cal Medicine, 76, 888.

Mannik, M., Haakenstad, A. O., and Arend, W. P. (1974) $\cong$ The fate and detection of circulating immune complexes $N$ Progress in Immunology, II, 5, p. 91. North-Holland Publishing Co.: Amsterdam.

Mulli, J. C., and Cruchaud, A. (1977). Immunoreactivity tao nuclear antigens in systemic lupus erythematosus, with or without nephritis, and in other connective tissue diseases $\stackrel{\oplus}{\longleftarrow}$ with particular reference to the RNA-protein antigen: International Archives of Allergy and Applied Immunology, 53, 279-289.

Onyewotu, I. I., Holborow, E. J., and Johnson, G. D. (1974) Detection and radioassay of soluble circulating immunep complexes using guinea pig peritoneal exudate cells? Nature, 248, 156-159. 
Rabinovitch, M., Manejias, R. E., and Nussenzweig, V. (1975). Selective phagocytic paralysis induced by immobilized immune complexes. Journal of Experimental Medicine, 142, 827-838.

Reikvam, A. (1977). The phagocytic capacity of macrophages in $\mathbf{S}$ phase of the cell cycle. Cellular Immunology, 31, 199-204.

Saragone, A. L., Jr., Kamps, S., Campbell, R., and King, G. W. (1977). Lack of correlation of activated monocytes with lymphocyte function in patients with lymphoma. Journal of the Reticuloendothelial Society, 21, 377-383.

Schmidt, M. E., and Douglas, S. D. (1976). Effect of levamisole on human monocyte function and immunoprotein receptors. Clinical Immunology and Immunopathology, 6, 299-305.

Symoeus, J. (1976). Levamisol technical report. Janssen Pharmaceutica Publications: Beerse, Belgium.

Utsinger, P. D. (1976). Lymphocyte responsiveness in systemic lupus erythematosus. Arthritis and Rheumatism, 19, 88-92.

Walker, W. S. (1974). Functional heterogeneity of macrophages: subclasses of peritoneal macrophages with different antigen-binding activities and immune complex receptors. Immunology, 26, 1025-1037.
Wenger, M. E., and Bole, G. G. (1973). Nitroblue tetrazonium dye reduction by peritoneal leukocytes from rheumatoid arthritis and systemic lupus erythematosus patients measured by a histochemical and spectrophotometric method. Journal of Laboratory and Clinical Medicine, 82, 513-521.

Weston, W. L., Duskin, R. D., and Hecht, S. K. (1975). Quantitative assays of human monocyte-macrophage function. Journal of Immunological Methods, 8, 213-222.

Wiener, E., and Bandieri, A. (1977). Differences in the immune and nonimmune interaction of peritoneal macrophages fromBiozzi high and low responder lines of mice with sheep red blood cells. Journal of the Reticuloendothelial Society, 21, 331-342.

Winfield, J. B., Faiferman, I., and Koffler, D. (1977). Avidity of anti-DNA antibodies in serum and IgG glomerular eluates from patients with systemic lupus erythematosus. Journal of Clinical Investigation, 59, 90-96.

Zurier, R. B. (1976). Reduction of phagocytosis and lysosomal enzyme release from human leukocytes by serum from patients with systemic lupus erythematosus. Arthritis and Rheumatism, 19, 73-78. 